\title{
Training Digital Literation by Digital Book Format Electronic Publisher Themes of Climate for Junior High School Students
}

\author{
SN Hidayati \\ Department of Science Education \\ Universitas Negeri Surabaya \\ Surabaya, Indonesia \\ sitihidayati@unesa.ac.id
}

\author{
Munzil \\ Departement of Chemisytry \\ Universitas Negeri Malang \\ Malang, Indonesia \\ munzil.fmipa@ac.id
}

\author{
Siska Vernanda \\ Department of Science Education \\ Universitas Negeri Surabaya \\ Surabaya, Indonesia
}

\author{
IW Dasna \\ Departement of Chemis Kralang, \\ Universitas Negeri Malang \\ Indonesia \\ idasna@um.ac.id
}

\begin{abstract}
This electronic document is a "live" template and already This study aims to train the digital literacy of seventhgrade junior high school students with electronic books in electronic publisher format. The book used in this study has been validated previously included in the category of very feasible. The design used in this study was the one-group pretestposttest design. The instruments used in the study were observation sheets for the implementation of learning, student response questionnaires, and about the pretest and posttest. Data collection methods are observation, questionnaire, and pretest-posttest. The data analysis technique uses the Likert scale and $\mathrm{N}$-Gain. The subjects of this study were 20 students at SMP Negeri 22 Surabaya. The results of the research on digital literacy abilities obtained by students based on the N-Gain score found 13 students experienced an increase in the high category and 7 students including the medium category. Student responses to the use of ebook books on average the results of students' responses to digital books by $97.5 \%$ like the use of ebooks
\end{abstract}

\section{Keywords - Digital books, digital literacy}

\section{INTRODUCTION}

Technology is one thing that cannot be separated from human life. All activities carried out by the community will not be separated from technological developments. Technology as an application of the development of knowledge has become a necessity that we cannot breathe in the current era.

The era of the industrial revolution 4.0 that we are familiar with in the era of disruption is accompanied by increasingly sophisticated technological developments and Claudy-based data. All information needs can be found in data sources that are no longer written in a printed document but are already in digital format scattered in cyberspace.

The use of data access devices is also no longer an extraordinary thing in this era. Gaged is one tool that is widely used to access all information needed through the virtual world (Claudy data). Its use also increases with increasing time, both from among children, adolescents, to adults. This development is followed by access to data that is getting bigger and wider, so the internet as a data network is also an inevitable need. Indonesia is one of the countries with

\author{
S wonorahardjo \\ Departement of Chemisytry \\ Universitas Negeri Malang \\ Malang, Indonesia \\ Surjani.wonorahardjo@um.ac.id
}

the largest number of internet users in the world. The Indonesian Internet Service Users Association (APJII) conducted research in 2016, the number of internet users in Indonesia was 132.7 million with details of $29.2 \%$ aged $>35$ 44 years, $18.4 \%$ aged $10-24$ years, $18 \%$ aged $45-54$ years, $10 \%$ are $>55$ years old, and $24.4 \%$ are $25-34$ years old. Whereas in 2017, the number of internet users in Indonesia ranged from 143.26 million with details of $4.24 \%$ aged $>54$ years, $29.55 \%$ aged $35-54$ years, $49.52 \%$ aged $19-34$ years, and $16.68 \%$ aged $13-18$ years. Based on these two studies, the number of internet users is increasing every year. Indonesian people are very dependent on smartphones and the internet [1].

Attitudes toward developments and changes in the era that occurs, of course, must be followed wisely between the benefits and also the adverse effects. So the skills in using and also accessing data from cyberspace become a mandatory skill that must be mastered to get results as expected. This is because literacy in the digital age / digital literacy is one of the skills that must be possessed in the 21 st century in addition to inventive thinking, effective communication and high productivity (according to NCREL and Metiri Group [2].

The concept of digital literacy in the late 1990s by Gilster in the world of education defined it as a unique and fundamental but revolutionary skill that digital literacy students must have in using their own digital devices. Skills for accessing specific information (eg, evaluations, searches) that are applied to text and multimedia information found on the internet and located in the context of school-based formal learning [3].

Based on research conducted by Amanda Rahmah in getting data that Indonesia users of social media are very high. This was followed by a trend of increasing gadget use/utility, Internet access becoming dynamic and practical. This data shows that Indonesian citizens have adopted digital technology with internet-based digital media that is accessed through gadgets, especially cellphones [4].

The education system in Indonesia refers to the curriculum regulated by the government. The 2013 
curriculum is expected to be able to develop national literacy through learning Indonesian through developing the ability to read, write and think critically supported by the School Literacy Movement. Currently, the applicable curriculum in Indonesia is the 2013 curriculum. The orientation of the 2013 curriculum development is the achievement of cognitive, affective, and psychomotor domains. The Minister of Education and Culture also enacted rule number 23 of 2015 concerning Growth of Character, which one of its implementations was the National Literacy Movement (GLN).

Technological developments urged the government to implement the Digital Literacy Movement. This is evident from the Ministry of Education and Culture issued sixteen digital books that can be used by students and the public. Digital literacy is defined as the ability to understand and use information in various forms from a very wide variety of sources that are accessed through computer devices. Humans can do anything using a smartphone, including teaching and learning activities, namely online tutoring, educational videos, and various digital books. The digital literacy movement in education is very much needed considering the rapid development of technology. Well-implemented digital literacy will also have a good impact on information literacy $[5,6]$.

This digital literacy skill must be part of learning if you want to be a skill that students must have. Skills that must be guided directly in learning. Then it is necessary to have a learning design in which to practice digital literacy skills. A rapid increase in the transfer of knowledge and also different technologies is a global phenomenon [7].

Learning should be interesting, challenging, fun and provide opportunities for students to be creative. Then there needs to be a change and set the context for theoretical models, curriculum design, and innovation in learning [8], states that the use of ebook as a learning tool is useful for increasing student motivation in reading. For readers who are still beginners, they will feel stimulated, motivation will increase, to read because the ebook can contain multimedia and multisensory features.

Ebook has several advantages over printed books (traditional books) including ebooks that are more accessible, easier to store because they only need a memory card, ebooks are easy to carry anywhere because they don't have the burden as printed books [9]. Electronic publisher (epub) is one of the technological developments in the field of education. Epub is a digital book standard (ebook) developed by the International Digital Publishing Forum (IDPF). This epub format can be accessed either online or offline through the device. Epub has complete features, namely text, images, audio, video, hyperlinks, and hypertext. This is very good to use in the learning process.

The book developed in this research is epub digital format book with digital literacy skills strategy. This development aims to train digital literacy skills in students. The use of epub is expected to be able to train digital abilities because students are taught how to access technology to understand learning material. Epub can load content such as hyperlinks that will guide students to learn to browse the internet to get information. Teacher guidance in training digital literacy is also needed. Students learn to browse information on the internet and teachers guide students to choose the information that is appropriate and which is not appropriate.

Climate change material is one of the basic competency demands 3.9, namely analyzing climate change and its impacts on ecosystems and 4.9 which is writing about the idea of adaptation/mitigation of climate change issues Climate change material has become an international issue today and studied by many people on various internet pages. A large number of studies on climate change can be a vehicle for students to improve digital literacy.

\section{METHOD}

This study uses the one group pretest-posttest research design. Researchers use textbooks in the form of digital electronic publisher (e-pub) books on climate change material that have been developed and validated. The study was conducted on students from class VII Surabaya 22 Middle School totaling 20 people in 1 class. The type of data obtained is quantitative data. The data obtained is then described descriptively.

The research instrument used was the implementation of learning sheets using e-books, student response questionnaires, pre-test, and post-test questions. Data collection methods used in this study were observation, questionnaire, pretest, and posttest. The results of the pretest and posttest data were analyzed using the Likert scale and the $\mathrm{N}-$ Gain score test.

\section{RESULTS AND DISCUSSION}

Based on the research that has been done the following data is obtained:

\section{a. Implementation of Learning Observation:}

The implementation of learning that was observed was the implementation of learning activities using digital books developed. Learning activities are conducted in three meetings, and the data obtained are summarized below.

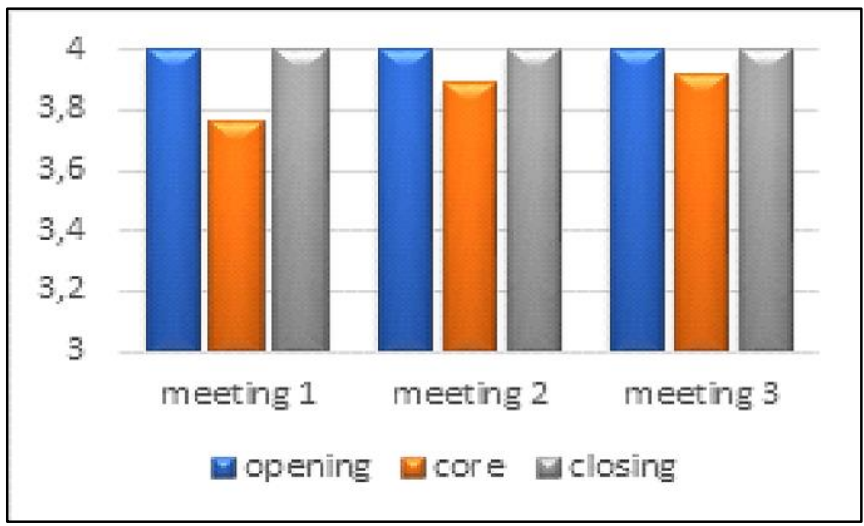

Fig. 1. Graft learning process

Based on Fig. 1. it can be seen that the ability of researchers in all meetings of the ability to open and close learning is very good. At the core activity, there is an increase from the first meeting to the next meeting. Thus, the results of observations on the implementation of learning using 
digital books can be said to be very practical. These results are in line with the research [10] students' interest in learning is directly proportional to the use of multimedia. This causes the learning atmosphere to be conducive so that the learning implementation plan can be implemented properly.

\section{b. Student Response Questionnaire Results}

Questionnaire for students 'response to learning activities using digital books developed to train digital literacy, is used to know students' responses to the digital book. The results of student responses after using digital books in the learning process are as follows:

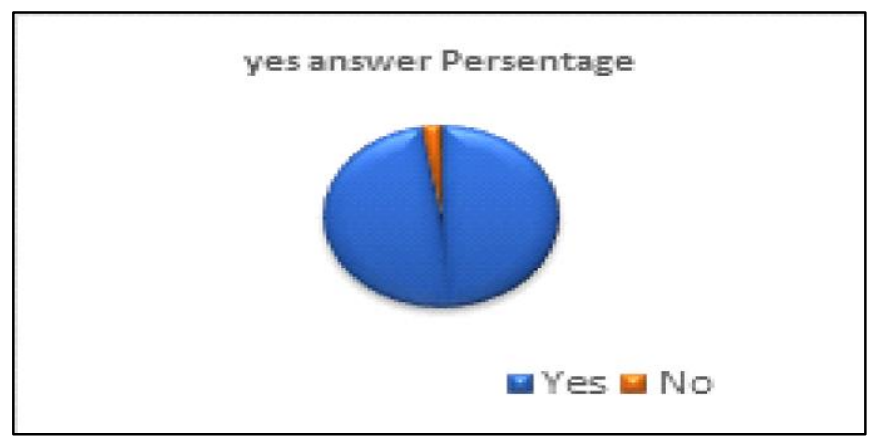

Fig. 2. Result for student response instrument

Based on the Fig. 2 Students' responses to the digital books developed showed a good thing with a percentage of "yes" answers of $97.5 \%$. According to the interpretation of the Guttman scale score in Riduwan (2012), the score is included in the excellent category. Digital books have many features to support the learning process and practice digital literacy. Digital books contain text, images, videos, hyperlinks, and hypertext. Munir (2012) states that the use of multimedia for reading can provide new nuances to obtain information. Multimedia that is accompanied by sound, images, music, animation, and video can turn on the text that is read so that the acquisition of information is better than just books with text.

Literacy in the digital era is an absolute necessity because the development of science and technology takes place very quickly. The ability of someone to search for information on the internet is also very important because through the internet can find information quickly (26). Digital books are designed to train students to digital literacy, students can practice the ability to search for information on the internet through the "Try Searching!" Feature, training the ability to read the news on the internet, knowing the functions of hyperlinks and hypertext can also gather information on the internet.

\section{c. Result N-Gain pre-test and post-test}

Digital books that were developed were reviewed from the results of the students' pretest and posttest. Pretest is done before students do the learning process using digital books and posttest is done after students have done the learning process using a digital book developed. The pretest and posttest were conducted to determine the differences in students' digital literacy abilities. The results that have been obtained show that the digital books developed can train digital literacy seen from the results obtained by students experiencing an increase after the use of digital books in the learning process. This increase is obtained through the features in the book that help students to obtain digital literacy skills. In addition, the existence of LKPD provided can also help students to explore information on the internet, find out the functions of hyperlinks and hypertext, evaluate content, and compile knowledge so that students can independently obtain complete information.

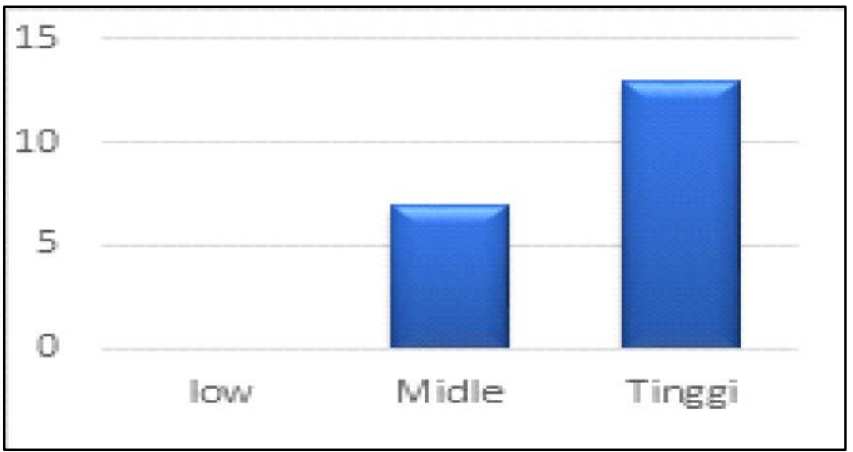

Fig. 3. N-Gain score category

Hake (1999) states that the results of the calculation of Ngain scores can be divided into three categories: low, medium, and high. Based on Fig. 3 shows that there were 13 students who experienced an increase in the high category and 7 others experienced an increase in the medium category. This is because to obtain maximum results, continuous learning is needed. This is in line with Gelder's research (2015) which says that to be an expert in a particular field requires a lot of practice.

As mentioned earlier, there are 4 dimensions of digital literacy that must be achieved by someone to be said to be digital literacy is the ability to search the internet, the ability to use hyperlink and hypertext functions, the ability to evaluate information content, and the ability to compile information. Based on the results obtained, the lowest results are found on internet searches. According to the AJPII survey (2017) regarding services that are widely accessed when using the internet is social media. Students find it difficult to find and find relevant webpages to get information that is in accordance with what is instructed. Research conducted by Hellara (2014) also states that students use the internet more for social networking than finding sources of information about learning.

The highest increase lies in the ability to use the functions of hyperlinks and hypertext. In the beginning, students did not understand hyperlinks and hypertext and their functions. After being explained and briefed students can quickly understand the function of hyperlinks and hypertext.

The overall N-Gain score can show that the digital book publisher (epub) format on climate change can train the digital literacy of seventh grade students in junior high school. Information technology that continues to advance must be utilized. The internet provides excellent benefits for education when used with supervision by teachers and parents. The teacher must train students to use the internet to help education, broaden their horizons and knowledge (13). Thus, digital literacy in students must continue to be trained. 


\section{CONCLUSION}

The conclusion that can be given by researchers based on the research that has been done is that electronic publisher format digital books on the theme of climate change are stated to be very feasible in terms of practicality. The practicality side is viewed from the implementation of the learning implementation plan (RPP) and student response. The implementation of the learning implementation plan (RPP) has increased at each meeting, both in the preliminary phase, core activities, and closing. The implementation of the learning implementation plan is included in the excellent category. Students' responses to digital books by $97.5 \%$ fall into the very decent category. Digital books on electronic format publishers on the theme of climate change were declared very feasible in terms of effectiveness with 13 students who experienced an increase in the high category and 7 students including the moderate category based on the $\mathrm{N}-$ Gain score.

\section{REFERENCES}

[1] Al Saadi, Khalid., Mary Lane Kelso., Anisa Al Hafeedh., Al Sheithani Zainab., Miriam Al Wishahi. 2017. Are We Ready for E-books? Omani University Students Uses and Perceptions of E-books. The Turkish Online Journal of Educational Technology Vol. 16, No. 2. Halaman 1112

[2] Arsyad, Azhar. 2016. Media Pembelajaran Edisi Revisi. Depok: PT Rajagrafindo Persada.

[3] Asosiasi Pengguna Jasa Internet Indonesia (APJII).. Info grafis Penetrasi dan Perilaku Pengguna Internet Indonesia. https://apjii.or.id/survei2017 (online).

[4] Badan Standar Nasional Penilaian, Instrumen Penilaian Buku Teks Pelajaran Pendidikan Dasar Menengah, Jakarta: Depdiknas, 2006.

[5] Badan Standar Nasional Pendidikan, Standar Isi Untuk Satuan Pendidikan Dasar dan Menengah. Jakarta: Badan Standar Nasional Pendidikan (BSNP). 2006.

[6] K. Ciampa, "Reading in the Digital Age: Using Electronic Books as a Teaching Tool for Beginning Readers," Canadian Journal of Learning and Technology, vol. 38, no. 2, pp 4, 2012

[7] M. Gosper, D. Ifenthaler, U. L Technologies, and H. Education, "Curriculum Models for the 21st Century (Gosper Maree, ed.)," https://doi.org/DOI 10.1007/978-1-4614-7366-4

[8] S. S. Hallera, "Penggunaan Internet pada Siswa kelas X dan XI SMAN 1 Pengasih,”. Skripsi: unpublished, Yogyakarta: UNY, 2014

[9] S. Huey, and G. Ming, "Design of Mobile E-books as a Teaching Tool For Diabetes Education," International Conference Mobile Learning 2017, 2017.

[10] C. Husain, "Pemanfaatan Teknologi Informasi dan Komunikasi dalam Pembelajaran di SMA Muhammadiyah Tarakan," Jurnal Kebijakan dan Pengembangan Pendidikan, vol 2(2), Juli 2014; 184192, (http://ejournal.umm.ac.id/index.php/jmkpp/article/viewFile/1917/202 2, downloaded 6 Desember 2018).
[11] Kemendikbud. 2017. Materi Pendukung Literasi Digital. Jakarta: Kementerian Pendidikan dan Kebudayaan.

[12] Kominfo.2014." GuruHarus Melek Internet" (online) .https://kominfo.go.id/content/detail/7674/guru-harus-melekinternet/0/sorotan_media. accesed: Januari 2019.

[13] R. C. Lowery, "Teaching and Learning with Interactive Student Response Systems: A Comparasion of Commercial Products in The Higher-Education Market," 2005. (lowery@uncw.edu). accesed: April 2019.

[14] E. M. Meyers, I. Erickson, and R. V. Small, "Digital literacy and informal learning environments: an introduction. 9884," 2013. https://doi.org/10.1080/17439884.2013.783597

[15] P. Odum and Eugene, "Fundamentals of Ecology. Georgia: University of Georgia," 1971.

[16] B. Plangsorn, and S. Poopan., "Development of Producing and Using E-books Competecies of Teachers in Chachengsao, Thailand," World Journal on Education Technology, vol. 09(02), pp 112-117, 2017

[17] H. Prasetyo, "Industri 4.0: Telaah Klasifikasi Aspek dan Arah Perkembangan Riset.” Jurnal Teknik Industri, vol. 13(1), pp 17-18, 2018

[18] D. Purwanto, "Pengembangan Media Komik IPA Terpadu Tema Pencemaran Air Sebagai Media Pembelajaran untuk Siswa SMP Kelas VII." Jurnal e-Pensa, (online), vol 01(01), 2017 (ejournal.unesa.ac.id/article/2692/37/article.pdf.

[19] A. Rahmah, "Digital Literacy Learning System for Indonesian Citizen," Procedia - Procedia Computer Science, vol 72, pp. 94-101, 2015 https://doi.org/10.1016/j.procs.2015.12.109

[20] T. P. N. T., Shariman, N. A. Razak, and N. F. M. Noor, "Digital Literacy Competence for Academic Needs: An Analysis of Malaysian Students in Three Universities," Procedia - Social and Behavioral $\begin{array}{llll}\text { Sciences, } & \text { vol } 69, & \text { pp: } & 1489-1496,\end{array}$ https://doi.org/10.1016/j.sbspro.2012.12.090

[21] A. Setiawan, "Analisis Kesesuaian Materi Ruang Lingkup Biologi pada Buku Teks Biologi SMA Kelas X dengan Kompetensi Dasar Kurikulum 2013," Unpublished thesis. Lampung: Universitas Lampung, 2018

[22] Slameto, "Belajar dan Faktor-faktor yang Mempengaruhi" Jakarta: Rineka Cipta, 2013.

[23] Sugiyono, "Metode Penelitian Kuantitatif, Kualitatif, dan R\&D," Bandung: Alfabeta, 2013

[24] Stone, susan.2010. Perubahan Iklim dan Peran Hutan. The Gordon and Betty Moore Foundation. www.epa.gov/climatechange/kids/climateweather.html (online). Diunduh pada: Febuari 2019.

[25] Sumiaty, Noneng dan Neti Sumiaty. 2014. Literasi Internet pada Siswa Sekolah Menengah Pertama. Balai Pengkajian dan Pengembangan Komunikasi dan Informatika Bandung (BPPKI) Bandung. bppkibandung.id/index.php/jpk/article/download/8/10 (online). Diunduh pada: Maret 2019.

[26] P. Turiman, J. Omar, A. M. Daud, and K. Osman, "Fostering the 21st Century Skills through Scientific Literacy and Science Process Skills," Procedia - Social and Behavioral Sciences, 2012 https://doi.org/10.1016/j.sbspro.2012.09.253

[27] UNESCO. Education for All : Literacy for Life, 2005, http://www.uis.unesco.org/Library/Documents/gmr06-en.pdf. 